\title{
TÁRSADALMILAG HASZNOS BEFEKTETÉSEK?
}

A cikk az úgynevezett társadalmilag hasznos befektetések fogalmát, az etikus befektetések minimumkritérium-rendszerét definiálja és elemzi azt, hogy ezek a befektetések ténylegesen eredményeznek-e össztársadalmi hasznosságot. Általánosan elfogadott definíció hiányában nehéz mérni, a hasznosságot és értelmezni az eredményeket. Jelenleg kizárólag az egyéntól, a befektetốtól függ az, hogy mit tart hasznosnak. A problémát valamennyire oldja az, hogy az egyik részterület viszonylag jól körülírható, és ezért jól dokumentált befektetési alapok a pénzügyi szempontok mellett speciális (a mi esetünkben társadalmilag hasznosnak ítélt) kiválasztási kritériumokat is használnak. A cikk hangsúlyosan ezeknek a befektetési alapoknak az eddigi eredményeit mutatja be és összegzi. A befejezố rész röviden összefoglalja, hogy milyen iparágak lehetnek a változás vesztesei és nyertesei.

\section{Kulcsszavak: befektetések, társadalmi hasznosság, befektetési alapok}

A befektetéselemzés többféle megközelítést használ az üzleti lehetőségek értékelésére, ezért nehéz, de elkerülhetetlen a társadalmilag felelős befektetések általános definiálása is. Míg egyes befektetốknek az ilyen típusú befektetés azt jelenti, hogy nem invesztálnak bizonyos termékeket (például cigarettát vagy alkoholt) gyártó vállalatba, addig más, társadalmilag szintén felelôs befektetốknek ugyanaz a cég akár el is fogadható.

Az egyik elsô olyan alapkezelő, amelyik társadalmilag felelős szempontok alapján hozott létre befektetési alapokat, Pioneer Fund néven jött létre 1928-ban, melyet az azt követó években több hasonló alap is követett. Ezek az alapok, amelyek valamelyik vallás, általában keresztény, etikai megközelítései alapján múködtek, nem kereskedtek azoknak a vállalatoknak a papírjaival, amelyek dohány- vagy alkoholtermékeket gyártottak. A vallási alapon befektetó portfólió kezelő́k nem feltétlenül tartoztak egy egyházhoz vagy vallási irányzathoz. A Pioneer-alapok nem voltak különösebben sikeresek a befektetốk körében (Renneboog - Ter Horst - Zhang, 2008). Az etikai alapon menedzselt alapok sikeréhez többek között a vallásostól eltérố szempontrendszer beemelése járult hozzá. Azóta ez a piac jelentôs mértékben növekedett, legalább két- száz alapkezeló és csak az Egyesült Államokban hat tôzsdére bevezetett olyan alap létezik, amelyik például környezetmegóvási vagy más társadalmilag hasznosnak ítélt szempontok alapján hoz befektetési döntéseket (Karlsson, 2006). Minden fontosabb alapkezelói szegmensben (pénzpiaci, tókepiaci, vegyes, kockázati tốke stb.) létezik már ilyen szempontokat is figyelembe vevố alap.

A társadalmilag felelôs befektetések népszerúsége abból a közfelfogásból származik, mely szerint a legtöbb vállalkozásból teljes mértékben hiányzik a társadalmi felelősségvállalás, ezért eza befektetéselemzésirendszer nemcsak egy új profitszerzési lehetőség, de támogatója egy új társadalmilag hasznos üzleti modellnek is (Schepers - Sethi, 2003).

A cikkben az etikus befektetéseknek a legjobban dokumentált és a szakirodalomban legtöbbször szereplő formáját, az alapkezelói tevékenységet mutatom be. Az elsố részben az etikus alapkezelôi tevekénység meghatározására törekszem, majd ismertetem a legfontosabb szúrési technikákat, valamint azt is, hogy ezek az alapok milyen erkölcsi fundamentumokon nyugszanak. A következô részben a társadalmilag felelôs alapok teljesítményét és értékelését mutatom be, míg az utolsó részben a várható tendenciákat vázolom fel. 


\section{A társadalmilag felelôs befektetések definíciója}

A téma fontosságának illusztrálására elöljáróban néhány adat: 2007-ben az Egyesült Államokban a professzionális alapkezelók által kezelt etikus lakosság és - ami még fontosabb - intézményi portfóliók értéke elérte a 2,7 trillió dollárt (=2700 milliárd dollár), megközelítóleg a piac 11\%-át. Ugyanez az adat Európában 2,7 trillió euró (=2700 milliárd euró), amely a piac megközelítőleg 17\%-a. A teljes vagyonkezelói piac közelített a 25 trillió dollárhoz (Zhang, 2008; és Moore Odell, 2008)
A társadalmilag felelốs vagyonkezelốk által kezelt vagyon változása az USA-ban 2005 és 2007 között

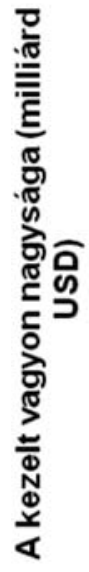

ját érdekeik alapján fontolják meg a befektetéseiket. Csak egy pontos, a piaci résztvevớk által is elfogadott meghatározás segítségével válna a vállalatok és a befektetők portfóliójában elkülöníthetôvé az etikus és a nem etikus tevékenység. Ma már jogos elvárás volna, hogy meghatározható legyen egy befektetési alap portfóliója annak alapján, hogy társadalmilag felelôs befektetés szempontrendszerét használó szereplôvel van-e dolgunk (Lundberg - Novak - Vikman, 2009). Szigorúan pénzügyi és befektetési szempontok miatt is szïkséges egy elfogadott definíció annak ér-

l. abra meghatározni a kockázat és a

1. ábra meghatazni a kockázat es a hozam összefüggését, egyáltalán azt, hogy társadalmi szinten lehetséges-e a hozamot (hasznosságot) mérni.

Fontos kérdés, hogy mi minősül egy adott korban és adott társadalomban felelős viselkedésnek, ezért a definíciónak kerülnie kell az értékalapú megközelítést. Szélsőséges esetben akár úgy is fogalmazhatunk, hogy minden, a gazdaságossági vagy pénzügyi elemzési kereten feliil megielenó elemzési kereten felül megjelenô szempontrendszer a társadalmiriába tartozik. Ez az értelmés riába tartozik. Ez az ertelmezés azonban túlságosan tág ahhoz,

Forrás: Social Investment Forum Foundation

Az 1. ábrán látható, hogy az etikai szưrési szempontok alapján befektetô alapok mérete 1995 és 2007 közö 324 százalékkal nőtt, és ezzel a dinamikája meghaladt a hagyományos befektetési alapok által kezelt portfólió növekedési ütemét (260 százalék) (2007 Report on Socially Responsible Investing Trends in the United States, Social Investment Forum, 2008). Az etikus alapok javára mutatkozó jelentős kïlönbség még akkor is kiemelt figyelmet érdemel, ha tudjuk, hogy 2008 ót globális gazdá́gi válúg hiatt az alapkezelók álta

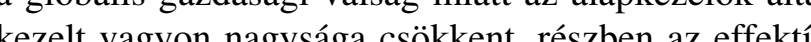
pénzkivońs, pénzkivonás, részben pedig a piaci érték alapján árazó számviteli módszerek (mark-to-market) miatt, és egyelôre nincsenek pontos adatok a két alapkezelói szegmens változtatásának a mértékéról.

A társadalmilag felelôs befektetéseknek nincs egységes és egyetemlegesen elfogadott definíciója. A definíció hiánya nemcsak a témával kapcsolato kommunikációt nehezíti meg, de lehetôséget ad arra is, hogy egyes gazdasági szereplók kizárólag a sa-

\section{Szempontrendszerek a gyakorlatban}

A már említett befektetési alapok a hagyományos gazdasági szempontokon kívül általában - a következókben ismertetett - szempontrendszerek kombinációjának segítségével hoznak befektetési döntéseket (O'Rourke, 2003). Hangsúlyozandó, hogy a kiválasztási folyam befejezése után a befektetéselemzés folyamata me egyezik a hagyományos, gazdasági szempontokat gyelembe vevố módszertannal.

- Kiválasztás

Ez az a szúrési szakasz, amikor valamilyen általános szempontrendszer alapján kiválasztják azokat a befektetéseket és értékpapírokat, amelyek megfelelnek az alap által a prospektusaiban meghirdetett társadalmilag felelős és/vagy környezetvédelmi szempontoknak.

Negatív kiválasztás

Ez a legrégebbi szúrési stratégia. Ha negatív kiválasztással élnek, akkor a teljes rendelkezésre álló befektetési univerzumból kizárják a társadalmilag veszélyes vagy a környezetszennyezó lehetőségeket. A napi tevékenységben ez egy, az alapkezeló által meghatározott negatív kritériumokat felsoroló lista segítségéve zajlik (például alkohol, dohány, fegyver, pornográfi nukleáris fegyverek, fogadásszervezés, gyermekmunka, munkavállalók kizsákmányolása és diszkriminalása, állatokon történố tesztelés, gyógyszeripar, húsfeldolgozó ipar, környezetszennyezó iparágak és azo finanszírozói stb.)

Egyes alapkezelóknek szigorúan távol kell tartaniuk magukat minden olyan vállalattól, amelyik a negatív kritériumok listájában felsorolt tevékenységben érdekelt, míg mások a már említett kizárási (cut-off) 10\%-os limitet alkalmazzák. Általánosságban azonban az alapkezelók nem publikálják a pontos szúrési szempontrendszereiket (Schepers, 2003). Miután a kizárás limit mértéke meghatározza a befektetési lehetőségek körét is, ezért a döntérozza a befektetési lehetóségek hanem pénzügyi szempontok is dominálhatnak.

A negatív kiválasztás nagy elönye viszonylagos egyszerúsége és olcsósága. Mindkét szempont, de fơleg az utóbbi, alapvetốen fontos a befektetési alapo résztvevóinek, mivel nyereségük az alap költségeinek a függvénye.

A negatív kiválasztás hátránya, hogy outsourcing vagy nemzetközi nagyvállalatok esetében a mai glob lis gazdasági rendszerben szinte lehetetlen az alvalla kozókat és a nemzeti vállalatokat, különösen azok etikai normáit és tevékenységét nyomon követni. További hátránya, hogy míg például a dohányipari vállalatokat kizárják, addig a velük kapcsolatban álló, a piacra jutá- sukat bonyolító cégeket (logisztika, kiskereskedelem, marketing) nem (Renneboog - Ter Horst - Zhang,

Talán az előzônél is lényegesebb probléma, hogy míg egyes vállalatok jól teljesítenek az etikai szempontrendszer jelentốs részében, addig más szempontokat tekintve megbuknak. Az alapok számottevô része ebben az esetben a vállalat bevételeire is a kizárási limitet alkalmazza, ami hüvelykujjszabályként itt is tíz százalék, vagyis maximum az alap értékének a tíz százalékáig fektethet az adott vállalatba. E kritériumrendszer eset́ben azon a nán a vallalatoknak tobb jatéteruik van, ezért az alapok portfoliójában felülreprezentáltakká válnak a kisebb cégekhez képest
(Schepers, 2003).

Pozitív kiválasztás

Ez a megközelítési mód eredetileg a negatív kiválasztásból alakult ki, mivel a befektetók a kizárás helyett az elfogadásra kezdtek koncentrálni. Ebben az esetben is egy szempontrendszert határoznak meg, amely azonban a negatív szúréssel szemben általában nem egyedi kizáró okokat tartalmaz. Például: az adot vállalat tevékenysége általában nem törvénysértő, nem végez környezetszennyező tevékenységet, vagy ha igen, akkor a kibocsátását nemzetközi szinten is elfogadható mértéken tartja, aláírta az ENSZ Global Conduct-ot, vagy például kizárólag környezetvédelemmel kapcsolatos technológiákat gyárt és forgalmaz (Schepers, 2003).

Ebben a megközelítésben az a fontos, hogy a befektetốk azokat a befektetéseket válasszák ki, amelyek megbízhatóak, valóban az alap cáljainak megfeleló tevékenységet folytatnak, és ezt bizonýt mi, dokútetálni is dják (megfeló a treck lalni is tudjuk (miválasztot cégeket minden esetben próbaljak teljes körúen megvizsgálni, mivel egy esetleges rossz választás negativiv publicitása miatt a késốbbiekben az alap rosszabb megítélés alá eshet.

A pozitív kiválasztás hátránya, hogy viszonylag kevés szempontot vesz figyelembe, ezeket a vállalatok nagy része ism vés écét megpróbálhatjók a sajút tevékenységük látható jellemzóit valamilyen módon manipulálni. Ezzel magyarázható az, hogy a befektési alapok a pozitív megközzlítésú szemoy a befektetési általában más módszerekkel együtt használják.

Kormányzati szervek is gyakran élnek pozitív kiválasztással, mert így könnyebb alulfinanszírozott alanyokat találniuk olyan területeken, mint a jelzáloghitelezés vagy a kisvállalkozás-finanszírozás. Ezek a területek a hagyományos befektetók számára nem elég vonzóak. 
- Best in class (legjobb a csoportban/osztályban Ebben az esetben egy adott iparágban próbálják az elfogadott szempontrendszer alapján azonosítani a több vállalathoz képest legjobban teljesítóket. A szempontrendszer meglehetősen sokféle lehet, például: maga termelési hatékonyság, környezettudatosság, társadalm felelősségvállalás, kutatás és fejlesztés, nôi menedzserek aránya a férfi menedzserekhez képest, termékbiztonság, kisebbségek védelme (O'Rourke, 2003).

Ez a stratégia a pozitív kiválasztás egy továbbfejlesztett változatának túnik, és a célja a vállalatok társadalmi felelősségvállalásának az ösztönzése.

A stratégiával kapcsolatban az egyik legnagyobb probléma az, hogy a szempontok gyakran nehezen megfoghatók, jelentôs értékítéletet hordoznak és nagy az információigényük, valamint - a pozitív kiválasztáshoz hasonlóan - a nagyvállalatokat preferálja, mive azok könnyebben megfelelnek a kiválasztási szempontoknak, például nagyobb az esélye a kisebbségi munkavállalóknak a közép- vagy felső vezetésükben, mint egy kisvállalat esetében (Schepers - Sethi, 2003).

A módszer ellenzói szerint ez nem más, mint szerecsenmosdatás, melyet a befektetôk akkor használnak, ha egy olyan befektetést akarnak igazolni, mely egyébkén az iparágban etikus befektetésként elfogato szent rendszernek nem felel meg (Mackenzie, 1998).

\section{- Kiszállás}

A kiszállással az alapkezelő az etikai szempontok alapján összeállított portfólió egyes elemeit akarja értékesíteni, azaz a befektetést követôen megpróbál k szállni abból a vállalatból, amelyikról utólag kiderül, hogy valamelyik szưrési feltételnek nem felel meg. A befektetéselemzés egyik elméleti tétele az, hogy a nagyszámú lehetóség miatt egy befektetés eladása nen lehet gond. A valóságban azonban a szigorú szứrési szempontok miatt lényegesen kisebb befektetési univerzum megnöveli a tranzakciós költségeket, és az alap újrasúlyozása is nehezebb. Az alapok mérete következtében a tranzakciós költségek hatványozottan jelentezen. Továbi cïts hogy nehéz elốre meghatározni a kiszállás idốpontját.

- Aktív részvényesi szerepvállalás

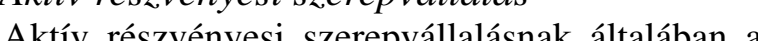
nevezzük, ha a részvényes nem csak pénzügyi befektetóként vesz részt az általa (akár részben) tulajdono vállalat irányításában. Az etikus befektetések vizsgálatakor kiindulási szempont, hogy az aktív részvényes részvételnek az a célja, hogy a befektetése a gazdasági eredményesség mellett további társadalmi értéket is teremtsen. Az értékteremtés érdekében a befektetók többnyire a társadalmilag felelós szempontrendszernek nem megfelelố vállalatokba fektetnek be, és a befektetési alap mint tulajdonos befolyásolni próbálja a cég menedzsmentjét. Mindezt abban a hitben teszik, hogy a társadalmilag felelős, környezettudatos részvényesek és a menedzsment együttmúködése társadalmilag hasznosabb szintre emeli a vállalatot. Ez az együttmúködés a közös fórumoktól kezdve a közgyúlésen történố szavazáson át az igazgatótanácsi tagságig, a harmadik országban történó befektetésektól a diszkriminációs kérdéseken, marketingtevékenységen keresztiil a vezérigazgatói javadalmaź́sig és a környezetvédelmi zéráseki terjedhet. Mindennek a a cólja hogén a válákt tećle lalat tevékenységét hosszú távon ne csak gazdaságilag is nyereségessé, de egyben társadalmilag felelôssé tegyék. Az amerikai társadalmilag felelôs befektetési alapok kb. 30\%-a aktív tulajdonosi részvétellel múködik (Sandberg, 2008).

Tény ugyanakkor, hogy a valós tulajdonosi szemlélet viszonylag ritkán jelenik meg (gondoljunk a tulajdonosok és a menedzsment között fennálló információs aszimmetriára), ezért fóleg nagyvállalatok esetében a valóságban nincs részvényesi kontroll.

Nagyobb probléma azonban a befektetési szúrók teljes hiónya a magukat aktív tulajdonosként definiáló alapoknál, s ez önmaǵban egyfajta kibúvónak tünhet a társ

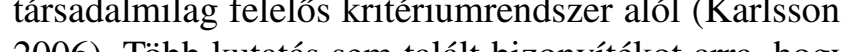
2006). Tobb kutatás sen talát bizonyitékot arra, hogy az aktív tulajdonosi részvétel megváltoztatta volna a menedzsment viselkedését. Scherpers (2003) ugyancsak kibávónak tartja az aktú tulajdonosi részvételt, mert általában az ún. etikus alapok a nem etikai szempontok alapján befektetó alapokkal azonos feltételek mellett fektetnek be

\section{Teljesítménymérési kutatások és eredményeik}

A társadalmilag felelós, környezettudatos befektetések támogatói szerint az elôzőekben bemutatott elemzés szempontrendszer rávilágít a vállalatok gazdaśgi teljesítményén olyan okira is, amelyck elsö pilla teljesim féćc nem felech ố je viszont minden olyan megközelités, amely korlátozza a rendelkezésre álló befektetési univerzumot, csökkenti hozamot vagy növeli a kockázatot.

A The Independent 2009. augusztus végén közölte az angol IMA (Investment Management Association) kimutatását, amely szerint 2008. július 1 . és 2009. július 1. között az etikai alapon múködő befektetési alapok értéke 16,7\%-kal, míg a hagyományos alapok értéke 12,3\%-kal csökkent. A hatvan társadalmilag felelós alapból összesen háromnak az értéke növekedett. Ezek az adatok kielégítik mind a tankönyvi kockázat-hozam elvárást (kisebb befektetési univerzum, magasabb kockázat), mind azt a logikát, amely szerint azoknak a vállalatoknak, amelyek anticiklikusak, a nagyobbik része nem felel meg egy társadalmilag felelós befektetetési szempontrendszernek. A fenti magyarázat mellett persze az is hozzájárulhat az etikai alapon múködó befektetési alapok relatíve nagyobb veszteségéhez, hogy a rövid távú hozam nagy valószínúséggel felértékelốdik a társadalmi felelôsséghez képest. A társadalmilog felelós befektetések anticiklikussága a tórsadalmilag felelós befekér sabb befiétés) vagy múkoödesi költségekbôl, válság idején elóóterbe kerül az alapvetố igênyek fentartása és az olcsóbb élvezeti cikkek. A következőkben bemutatandó kutatások árnyalják ezt a képet.

A legtöbb kutatás a befektetési alapok és egy kiválasztott piaci index vagy egy mesterségesen összeál tott benchmark (átlagos piaci) portfólió segítségéve próbálta mérni és magyarázni az eredményeket. A kutatások nagy része az Egyesült Államok, az Egyesült Királyság és Ausztrália piacára koncentrált. Ennek egyik oka az, hogy ezekben az országokban a legnépszerúbb a társadalmilag felelós befektetésialap-kezeló piaca, és emellett általánosságban is ezekben az orszá gokb es ér gor

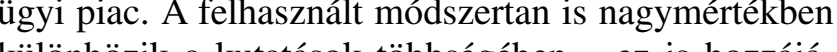
külón rulhat az igen eltéró eredményekhez. A kutatások egy része azonban statisztikailag szignifikáns különbsége talált a hagyományos és a társadalmilag felelós alapok tevékenysége között (Benson - Brailsford - Humphrey, 2006).

A kutatások fő megállapításai a következók szerint öszszegezhetók:

Az egyik legkorábbi kutatás Angliában (Luther -, Matatko és- Corner, 1992) 1984 és 1990 között vizsgált 15, az Ethical Investment Research Service definícioja (minden ide tartozott, ami nem csak pénzügyi elemzesi szenpontokat hasznili) alapjon milag felelos alapot. Hagyományos alopok teljesítményét nem vizscáták, és csak

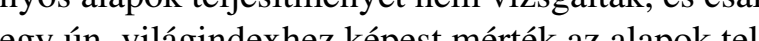
jesítményét. A havi Sharpe- mután ás Jenok teljesinjényet. A havi Sharpe-mutató és Jensen-alfa alapján az eredmény a benchmark indexet felümúlta, azonban ez az eltérés nem volt szignifikán A kritikusok véleménye szerint a kiválasztott alapokban túlreprezentâltak voltak az ún. small capek (kisebb vállalatok), és a választott időszak sem reprezentálta megfelelóen a piaci ciklusokat. To- vábbi probléma származott a definícióból is, mivel olyan vallásos alapok is bekerültek a 15 alap közé, amelyek nem határozták meg magukat társadalmilag felelôss alapként, ez pedig torzíthatta az eredményeket (Schepers - Seti, 2003).

- Az angol hagyományos és társadalmilag felelós alapok teljesítményét összehasonlító másik kutatás során (Mallin Saadouni - Briston, 1995) a kutatók az akár pozitív, akár negatív portfóliószúrési módszert használó alapokat is a társadalmilag felelősek közé sorolták. A kutatás eredménye szerin a hagyományos és a tris a er, sh, minsen-alfa és Sha a hagyományosakat. A kritikák jelentốs része a kiválasztási folyamatra irányult, mivel a kutatók egyáltalán nem publikálták, hogy az egyes alapok milyen módszertant használtak.

Évekkel korábban a Financial Analyst Journal 2000. május-júniusi kiadásában megjelent cikk szerzóje (Meir Statman, 2000) 31, társadalmilag felelós szempontok alapján kiválasztott befektetési alap esetében viszont azt tapasztalta, hogy azok hozama meghaladta a hagyományos befektetési elemzés alapján összeállítottakét. Igaz, a teljesítménykülönbség statisztikailag elhanyaz, a teljesítA nyil azo Annyi azonban az elemzés alapján kinyilvanítha, alapok teljesítménye nem külonbözik jelentősen a tôbbi hagyományos alapétôl, az ezekbe történố befektetés tehát nem feltétlenül jelent alacsonyabb hozamot.

- Egy 60 angol, svéd, német és holland etikus és hagyományos alapot 1995 és 2001 között vizsgáló 2005-ös kutatás szintén azt találta, hogy mind a két alaptípus a piaci index teljesítménye alatti eredményt ért el, illetve azt, hogy az etikus alapok nem szignifikánsan, de felülmúlták a hagyományosaka (Kreander - Gray - Power - Sinclair, 2005).

- A Fama-French-Carhart benchmark modell alapA Fama-French-Carhart benchmark modell alapján végzett kutatás (Rennebog - Ter Horst - Zhang, 2008) arra a következtetésre jutott, hogy az etikus alapok minden mutató alapján alulteljesítenek a hagyományosakhoz képest, azonban a különbség csak a japán, a svéd és a francia piacon szignifikáns, míg a többi piacon (köztük az Egyesült Államokban és az Egyesült Királyságban) nem. A szerzők szerint a befektetốknek felárat kell fizetniük, ha etikus alapba akarják fektetni a pénzüket.

- A Domini 400 Szociális Index teljesítménye adhat egyfajta magyarázatot arra, miért nem feltétlenül 
kell a profitot feláldoznia a befektetőnek, ha társadalmilag is felelősen akar eljárni. A DSI-t 1990ben hozták létre, és ez volt az elsô ún. benchmark részvényportfolió, amely egy több szempontbó álló társadalmi felelősségrendszer igényeit is kielégítette. A DSI egy piaci kapitalizációval súlyozott index, amit az S\&P alapján modelleztek, és alapítása óta túlteljesítette a normál indexet. Természetesen egy adott index összehasonlítása egy benchmark-kal meglehetôsen önkényes megoldás, és az eredmények pontos értékeléséhez ismern kell mind az index, mind a benchmark portfolo változásait (Meir Statman, 2000). - Egy, az ausztrál piacra vonatkozó kutatás (Jones an der Lann - Frost - Loftus, 2008), amely 89 etikus alapot vizsgált, 1986 és 2005 kôzott azt találta, hogy az etikus alapok szignifikansan, 3-5\%-kal piaci benchmark alatt teljesítettek az idószak egeszét nézve. Éves szinten átlagban az alulteljesítes 0,88\% volt, míg az idôszak utolsó öt évében éves szinten $1,52 \%$

- 2000-ben egy 1146, magát etikai elveket valló befektetóként definiáló egyén (és nem alapok) meginterjúvolásával készült kutatás (Lewis és- Mackenzie, 2000) szerint ezek a személyek vegyesen tartják a társadalmilag felelôs és a hagyományos vállalatok

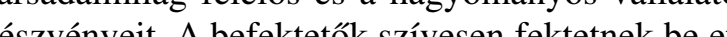
cénzvenyet. A befek

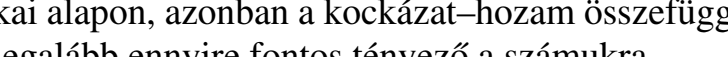
- egalább ennyire fontos tenyezó a szân

A Svéd Környezetvédelmi Ugynökség által 1999 és our kozôt végzett kutatás résztvevơi szerint nen a befektetési alap definíciója volt a legfontosabb, hanem a portfóliómenedzserek hozzáértése és tapasztalata.

Egy szintén Svédországban 2000 és 2007 között, 175 alap teljesitménye alapján készült kutatás arra az eredményre jutott, hogy az etikus alapok teljesítménye 2004 és 2006 kivételével minden évben szignifikánsan alulmúlta a normál alapokét. 2004 és 2006-ban nem szignifikánsan, de az etikus alapok múlták felïl a hagyományos alapokat. Érde-

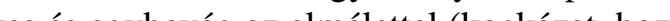

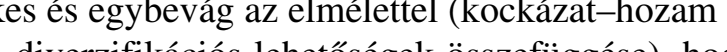
a diverzitikációs lehetôségek ơsszefuggése), hogy azokban az években, amikor a gazdaság teljesítménye csókkent, akkor az etikus alapok eredménye lenyegesen elmaradt mind a benchmark, mind hagyományos alapokétól.

Ez a kutatás azt is kimutatta, hogy mind a hagyom nyos, mind a társadalmilag felelós alapok befektettek olyan vállalatokba, amelyeknek a tevékenysége, elosztó hálózata, múködése nem volt minden szempontból etikus.
Az elemzés során az is láthatóvá vált a portfólió izsgálatakor, hogy a mintában megtalálható hagyományos svéd alapok leginkább az Egyesült Államok piacán, míg az etikus alapok 2003-ig a svéd piacon fektettek be, utána viszont ezek az etikus alapok is szinte kivétel nélkül az USA-ba csoportosították át a befektetéseiket. Ennek oka a stabilabb, transzparensebb és nagyobb amerikai piac lehet

Ugyancsak ez a kutatás jelezte azt is, hogy míg a hagyományos alapoknál egy portfóliókezelő általában több alapot is menedzsel, addig az tikus alapokńl egy alap - egy menedzser a jellemző (Lundberg - Novak Vikman, 2009).

\section{A piacok szerepe}

Az elốbbi, szinte kizárólag befektetôii megközelítéssel zemben ebben a részben a reálgazdasági szempontok, az ágazati osztályozások és a gazdasági reakciók ismertetése dominál

Feltételezzük, hogy a vállalatoknak tudniuk kell, hogy a teljes termelési folyamat során mekkora a széndioxid-kibocsátásuk. Nemcsak a kormányok, de az üzleti partnerek, a társadalom, és végsô soron a befektetốk és részvényesek is pontosan szeretnék ismerni ezt azz adatot. A kibocsátást ugyanis elóbb vagy utóbb költsé folyásolja a cég által lérhetó profitot, és így a tulajdonosok jövedelmét.

A nem feltétlenül társadalmilag felelős szempontokat követố vállalatok már jelenleg is érzékelik azt, hogy az energiagazdálkodás korszerúsítése és racionalizalása elkerulhetetlen, mint ahogyan azzal is tisztában vannak, hogy ez hosszabb távon előnyökkel jár mind az adott vállalatra, mind a termelési folyamatra nézve. Ebben a tekintetben azok a cégek járnak az élen, amelyeknél erôs a vállalatirányítási politika. A McKinsey tanácsadó csoportnak az S\&P-indexet alkotó cégek körében elvégzett felmérése szerint az erôs irányítási rendszerrel rendelkezố vállalatok hosszabb távon a piacon felül teljesítenek (Foster, 2002).

Altalánosságban igaz az, hogy a fogyasztók igényei, a piaci kereslet határozza meg, hogy a cégek milyen termékeket kínálnak. Minden egyes olyan alkalom, amikor a környezetre kevésbé káros termékek jelentőss társadalmi népszerúségre tesznek szert (például: hibrid üzemanyagmeghajtású autók vagy energiatakarékos izzók), komoly jelzés a piaci szereplóknek más, a környezetet kevésbé szennyezố termékek fejlesztésére és kinalatára is. Végsố soron késóbbi tendenciákat vetítenek elóre a mindenkori aktuális trendek. Ennek a folyamatnak is, mint mindig, lesznek győztesei és vesztesei a jōvốben.

\section{A várható vesztesek: a nehézipar és a}

\section{energiaszektor}

A környezettudatos befektetốk további térnyerése az emiatt várható költségnövekedés kockázatának le nagyobb mértékben kitett terület a nehézipar, példáu az elektromosáram-termelés, az olajfinomítás vagy a faipar, de megemlíthetốk még a széntüzelésú erơmúvek is, melyek bár hatalmas szén-dioxid-kibocsátók, egy jô ideig mégsem zárhatók be. Ennek oka, hogy például az Egyesült Államokban ezek az erômúvek szolgáltatj Egesult Alla majdnem az en Energy adatai alapjan), és jelóng nem állnak rendelkezésre ezt a mennyiséget helyettesíteni képes alternatív erơforrások. (A kiotóoi egyezmény szerinti bázisé ben, 1990-ben a kibocsátot szén-dioxid-mennyiség töb mint 45\%-a származott az USA-ból és Oroszországbó A fejlódő országokban a széntüzelésû erőmúvek aránya az energiagazdálkodásban még jelentôsebb.

$\mathrm{Az}$ EU ETS kvótakiosztási rendszere a tervek szerint 2013-tól változik. A kiosztási tervek nemzeti szintról uniós szintre kerülnek, tehát az egyes ipa objektumok kvótáiról is az unióban döntenek. Az ingyenesen kiosztható kvóta mennyisége az ipari létesítmények számára benchmark (itt: az elérhetố legjobb technológia) alapon kerïl megállapít́sra. Ez pedig aztés jechnoti, hogy a válla kedig azt jelenti, hogy a vallalatoknak az elơre meghatározott és a korábbiakn (jelent kibocsát si lehetôség felett minden kibocsátásért fizetniük kell. A kiosztási rendszer tervek szerinti módosulása esetén a széntüzelésú erốmúvek direkt költségei minden újab tonna szén-dioxid-kibocsátással emelkednek, ezért az erômúveknek vagy az átlagos kibocsátásaik, vagy a rôvid távú profitkilátásaik jelentôs mértékben csökkennek

\section{Akik középen ragadhatnak: a pénzügyi} vállalkozások

A pénzügyi vállalkozások meglehetósen ellentmondásos helyzetú csoportot képeznek, mivel egyfelö jelentősek a lehetőségeik a tórsadalmilag felelős, kö nyezetbarát növekedésre, másfelől azo jectur kockázá vekedés varható a felelösségbiztosításokkal kapcsolatos kárteritések teruletén. A biztositótársaságok bevételeit számottevố mértékben növelheti a fokozott társadalm elvarások kovetkezteben egyre szigorúbb szabályoz környezet (a vállalatok magasabb prémiumot kénytelenek fizetni a szén-dioxid-kibocsátásuk miatt kialakulo egészségkárosodási kockázatok okozta perek miatt). Ennek elkerülésére a biztosítótársaságok emelhetik díjaikat vagy csökkenthetik a kártérítési kötelezettségeiket is. Azonban a verseny következtében feltehetôen akkor járnak a legjobban, ha egyfajta kompenzációt építenek be a termékeik árába azon vállalatok számára, amelyek hajlandók a kibocsátásaikat csökkenteni, vagy kár szén-dioxid-semlegessé válnak.

A bankoknak várhatóan ugyancsak módosítaniuk kell a hitelezési politikájukat a társadalmi és szabáyozói környezet esetleges változása miatt. Az egyre szigorúbb környezetvédelmi szabályozás, a jelentős összegú kártérítési kötelezettségek nagymértékben kihatnak majd a hitelfelvevoók eredményére és cashflow-jára. Emellett a pénzintézeteknek a saját üzemi múködésiiket (papírfelhasználás, autóhasználat stb.) is racionalizálniuk kell.

\section{És a nyertesek: a zöldek}

A foly tok lesznek, amelyek képesek gazdaságilag hatékony és emellett a vasararlóik által ,zöld "nek tekintett termékeket létrehozni és szolgáltatásokat nyújtani. Nem meglepő módon, a vesztesek között említett energiaszektorba tartozó cégek mindegyike megpróbál a megujuló energiák felé nyitni, és mindezt komoly vállalati PR-kampányok keretében kommunikálni is. A „zöld” termelốk és iparágak, amelyek képesek hosszú távon hatékonyan és fenntarthatóan a számukra engedélyezett maximum alá csökkenteni a károsanyag-kibocsátásaikat, további tartós profitra tehetnek szent a meg-

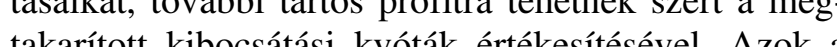
en,

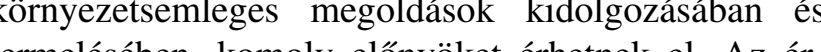
chesíthen, kornoly elónyöket énetnek el. Az ertékesíthetô kvơtákon túl ugyanis támogatások és adókedvezmények igénybevételével tovább növelhetik a nyereségüket. Ez pedig különösen fontos lehet az új, induló vállalkozások első éveiben, amikor még minden erơforrással szúkösen kell bánniuk.

Azok a vállalatok, amelyeknek további kvótákat kell vásárolniuk a magas kibocsátásaik miatt, középés hosszú távon jelentôsen csökkenthetik a költségeiket társadalmilag tudatos, környezetbarát termelési megoldásokra törekvő fejlesztésekkel vagy alternatív megold́s át, péld́ul erdóteleṕt́ssol, alternatív

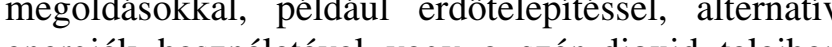
vagy a szén-dioxid talajban

\section{Összegzés}

A befektetốk, tulajdonosok számára az utóbbi évtizedekben kikristályosodott az a szempontrendszer, amelynek a segítségével szét tudják választani a hagyomanyos és a környezettudatos fejlesztéseket és tevékenységeket. Elemzések, kutatások pedig azt is igazolták, hogy a társadalmilag felelôs szempontok 


\section{CIKKEK ANGOL NYELVÜ ÖSSZEFOGLALÓI}

szerint összeállított alapok teljesítménye nem különbözik jelentősen a többi hagyományos alapétól, az ezekbe történő befektetés tehát nem feltétlenül jelent alacsonyabb hozamot.

Egyes vállalatok a változások éllovasaivá válnak, más cégek várakozó álláspontra helyezkednek és kivărnak, reménykedve a szabályozói és a társadalmi környezet elvárásainak a puhulásában. Ezek a cégek azonban nemcsak azt kockáztatják, hogy a késóbbi átállási költségeik várhatóan lényegesen magasabbak lesznek, hanem azt is, hogy versenytársaik mind tudásban, mind részvényesi imidzsben túlszárnyalják ốket.

E folyamat során várhatóan új iparágak alakulnak ki, új piacok és termékek jönnek létre. A társadalom és a piacok együttesen fogják meghatározni a környezetszennyezés aktuálisan még tolerálható szintjét és annak

Az újonnan kialakuló és az átalakuló régi iparágak hosszú távú gazdasági hatékonysága és a befektetốk szempontja szerint - amint azt a kutatások nagy része is bizonyította - a legfontosabb a transzparencia. Megfelelóen transzparens gazdaság és gazdasági szereplók esetén igazából nincs/nem volna értelme a társadalmilag felelős és hagyományos befektetés között különbségtételnek, mert a befektetố maga is el tudj tudná dönteni, hogy mibe fektessen, és ebben az eseten a megtakarításait mindenki a saját preferen az eseben a nogtán hón lamint a ván hó kockázat es hozam alapján allokáljo/ allokálná. Azonban, mint azt az elmúlt két év pénz- és
tốkepiaci eseményei, az azokra adott politikai reakciók tókepiaci eseményei, az azokra adott politikai reake

Lábjegyzet

'Sharpe- mutató egy porttóliónak a kockázatmentes hozamon felüli várható (átlagos) hozamát viszonyítja a hozam szorásához, tehát az adott portfólió teljesitményét a kockáz egységére jutó többlețövedelmezőség segítségével értékeli. Jensen-alfa esetéén a befektetés (portfólió) hozamából kilában a CAPM-modellel mériük. Ha az alfa értéke aoziA Treynor-mutató például - a Sharpe-mutatóhoz hasonlóan, - a kockázat egységére jutó jövedelmezőséggel definiálja a teljesítményt, a kockázat mérésére azonban a piaci béta mutatót alkalmazza.(Wikipedia.org)

\section{Felhasznált irodalom}

2007 Report on Socially Responsible Investing Trends in the United States, Social Investment Forum, 2008

Benson, K.L. - Brailsford, T.J. - Humphrey, J.E. (2006) Differently? Journal of Business Ethic hosszú távú termelési költségeit. tív, akkor a piaci portfólió feletti hozamot sikerült elérni. Do Socially Responsible Fund Managers Really Invest
Foster, R. (2002): The Pace of Change, www.mckinsey.com riffin, R. (2009): Ethical Funds are a Good Way to Invest Money - in Principle. The Independen

Jones, S. - van der Lann - Frost, G. - Loftus, J. (2008): The Investment Performance of Socially Responsible Investment Funds in Australia. Journal of Business Ethics Warming: Summary. http://environment.yale.edu/news/

Ris, A. - Mackenzie, C. (2000): Morals, Money Ethical Investing and Economic Psychology. Human Relations

Lundberg, L. - Novak, J.- Vikman, M. (2009): Ethical vs Nonor Enical and Non-Ehical Investment Furds

Luther, R.G. - Matalko (1994): The Performance of Ethical ish Accounting Review Investments. A European Review

A nancial Performance of Ethical Investment Funds. Journal of Business Finance \& Accounting

oore Odell, A. (2008): SRI Assets Surge Ahead. www.sriadviser.com

Rourke, A. (2003): The Message and Methods of Ethical Investment. Journal of Cleaner Production Price or Ehics and Stakeholder Governance. The Performance of Socially Respomitic Moverat Fun

Renneboog, L. - Ter Horst, J. - Zhang, C. (2008): Socially Responsible Investments: Insgtitutional Aspects, Performance, and Investor Behavior. Journal of Banking and Finance

Sandberg, J. (2008): The Ethics of Investing - Making Money or Making a Difference? Acta Universitatis Gothoburgensis. Gotebor

Schepers, D.H. (2003): A Criticque of Social Investing's Diversity Measures. Business and Society Review

Fund. A. - Sethi, P.S. (2003): Do Socially Responsible Funds Actually Deliver What They Promise? Business and Society Review

Statman, M. (2000): Socially Responsible Mutual Funds. Financial Analyst Journa

UNEP (2009): Global Trends in Sustainable Energy Investment 2009

$U S$ Department of Energy, www.energy.gov/energysources/ coal.html. Wikipedia.org

Zhang, C. (2009): Ethical Funds and Socially Responsible Investment: An Overview. http://www.qfinance.com/ investment-management-best-practice, Qfinance.com

Cikk beérkezett: 2010. 6. hó

Lektori vélemény alapján véglegesítve: 2010.10 . hó Leiserowitz, A. (2007): American Opinions on Global Ethical- Is The a Difference? Analyzing Performance Unit Trusts: Choosing An Appropriate Benchmark. Bri-

(1998): The Choice of Criteria in Ethical

Renneboog, L. - Ter Horst, J. - Zhang, C. (2008): The

\section{NEMES, Ferenc - SZLÁVICZ, Ágnes}

The role of management

in employees' job satisfaction

The study explores the relationship between the varous aspects of management styles and employees' jo satisfaction. Relevant literature and the desk research of 'Hungarians at Work 2006', a national job satisfaction survey have unequivocally found that management style plays a crucial role in employees' job satisfaction. A strong correlation has been shown between employees' job satisfaction and general management practices, whereas a significant correlation has been identified between employees' general satisfaction and the management style of employees' immediate superiors in sme-

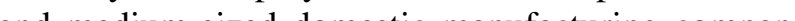
fully or partially ow fully or partilly ow dince h man resonces prowessionas have hich rensibility for forming management practices which improve organisa tional efficiency and meet employees' expectations they should assume a central role in enhancing job satisfaction among employees.

\section{BORSI, Balázs - LENGYEL, Balázs}

Context dependence of public sector innovations The examples of national natural science and technoogy education, and foreign language teaching

The study examines two areas: the education of natural sciences and technology and the teaching of foreign languages. It seeks to demonstrate how significantly the complicated context of innovations and the flow of knowledge can and may affect the development of innovations. In their study the authors consider the environment defined by disciplinarity as the context, an focus on those elements, in case of which interaction with innovations proved to be explorable ed.

\section{SZABÓ, József - FARKAS, Szilveszter}

The effects of the crisis in the Hungarian small and medium size enterprise sector

The economic crisis lasts for two years now. In 2009 and 2010 the authors examined the domestic small enterprises regarding their losses they have suffered, what they have done to avoid them, and what expectations they have for the future. Their surveys focus was the small and medium size enterprises in Gyôr and its surroundings. They found the first devasting phase of crisis in 2009, and the forecasts were pessimistic. Now, a year later they can say that the expectations were proved: the crisis is deep and long-lasting. The facts of 2009 destroyed the quick recovery. In 2009 the crisis management began using traditional instruments, later the deepening crisis caused the focus to shift towards long-term reorganization of the market relationships and resources. Based on the 2010 survey the authors identified three patterns of changing enterprises: basic-, winner- and loser-pattern. An important finding is that the majority of companies did not respond to the crisis, did nothing to ensure their future development (75\% basic-pattern and 16\% loserpattern) and just a few companies fell into the winnerpattern $(13 \%)$.

\section{FLASKÁR, Anett}

Franchise Systems:

An Explanation in the Framework of the New Property Rights and Agency Theories

The paper is concerned with analyzing the structure of franchise systems in the framework of the contractual theories of the firm, namely the new property rights and agency of the answers of the lit enture to the questionm of what the ansers of tie lit eatye to detennes (1) the proportis (2) the franchise fee and (3) the provisions in franchise contracts. The paper highlights the differences in the approach of the two theories: in the new property rights theory the answers to the above questions depend on the distribution of intangible assets between the franchisor and the franchisee, while the agency theory gives importance to monitoring costs in determining the above three. The paper summarizes also the related empirical results. 